\title{
Evaluation of silent cerebral ischemia and cognitive functions in young and middle- aged patients with metabolic syndrome
}

Gulmine Dundar ${ }^{1}$, Sehnaz Basaran²

${ }^{1}$ Department of Neurology, Kocaeli State Hospital, Kocaeli, Turkey

${ }^{2}$ Department of Neurology, Health Sciences University, Derince Training and Research Hospital, Kocaeli, Turkey

\section{ABSTRACT}

Aim: Metabolic syndrome (MetS) risk factors and accompanying silent cerebral ischemia (SCI) may cause cognitive decline. The aim of this study is to investigate the characteristics and association between SCIs and cognitive functions in young and middle- aged patients with MetS.

Methods: A total of 91 patients who were aged between 20-60 years with a diagnosis of metabolic syndrome were prospectively enrolled. Silent cerebral infarcts (SCIs) were analyzed by performing 3 Tesla magnetic resonance imaging (MRI) of the brain. Attention and executive functioning were assessed with the Wechsler Adult Intelligent scale-Revised (WAIS-R), verbal fluency, Stroop, and clock drawing test. Wechsler Memory Scale-Revised (WMS-R) visual reproduction and Öktem verbal memory processes tests were conducted to determine visual and verbal memory performance, whereas visuospatial functions were evaluated by the Benton judgment of line orientation test.

Results: Diagnosis of hypertension and diabetes mellitus were significantly higher, while educational level was lower in patients with SCIs than without SCIs. ( $p<0.001, p=0.034, p=0.05$, respectively). Cognitive test scores regarding attention and executive functioning, verbal, visual, and visuospatial memory showed no significant difference between patients with SCIs and without SCIs. However, hyperhomocysteinemia was negatively correlated with executive functions in MetS patients with SCI $(p=0.038)$.

Conclusions: SCIs may be associated with hypertension and diabetes mellitus in young and middle-aged patients with MetS. In addition, controlling homocysteine levels might be beneficial in MetS patients with SCI in terms of improving cognitive functions.

Key words: Metabolic syndrome, silent cerebral infarcts, cognition, executive functions, memory.

$\triangle$ Dr. Sehnaz Basaran

Department of Neurology, Health Sciences University, Derince Training and Research Hospital, Kocaeli, Turkey

E-mail: basaransehnaz@yahoo.com

Received: 2021-12-09/Accepted: 2021-12-26

Published online: 2022-01-01

\section{Introduction}

Metabolic syndrome (MetS) is an endocrinopathy characterized by a prothrombotic and proinflammatory process resulted in abdominal obesity, hyperlipidemia, high blood pressure, and insulin resistance [1]. MetS and its components are associated with an increased risk of cardiovascular and cerebrovascular diseases [2,3]. Moreover, in the last few decades, a combination of genetic tendency and unhealthy lifestyle choices such as low physical activity, and progressive weight gain leading MetS as a prominent public health issue $[4,5]$.

Silent cerebral infarct (SCI) is an incidental condition detected by neuroradiologic 
evaluation [as performed with computed tomography (CT) or magnetic resonance imaging (MRI)] without any neurological symptoms or deficits This term was first described by Chodosh et al. in 1988 , and classified as a subtype in "cerebrovascular diseases III" by the National Institute of Neurological Disorders and Stroke (NINDS 1990) $[6,7]$. The prevalence of SCIs in the general population ranging from $10 \%$ to $28 \%$ $[8,9]$.

Previous studies have suggested the significant association between SCIs, periventricular, and subcortical white matter hyperintensities, and MetS [10, 11]. Additionally, the presence of SCIs may be an initial process for cognitive dysfunction and vascular dementia [12-14]. However, studies about the relationship between vascular changes and cognitive functions in patients with MetS have been highly controversial due to the variabilities in neurocognitive assessment tools and sampling methods [13-15]. Based on our knowledge, no study has assessed SCIs and cogitive functions in young and middle- aged people with MetS. Hence, we aimed to explore the possible association between MetS components, SCIs, and cognitive performance on these subjects.

\section{Materials and methods}

\section{Study design}

Our study was performed at endocrinology and neurology outpatient clinic in Kocaeli University Medicine Faculty. The study protocol was approved by the local ethics Committee which is in line with the Helsinki Declaration (2009/98, AEK-12/17). Written and informed consent was obtained from all subjects prior to participating.

\section{Study population}

All subjects were prospectively recruited from endocrionology clinic in a tertiary care hospital.
Before the initiation of neuroradiologic and cognitive assessment, the diagnosis of MetS was made in accordance with the NCEP ATPIII criteria [16]. This syndrome was defined by an alteration in $\geq 3$ of the following 5 criteria: (i) waist circumference of the males $>102 \mathrm{~cm}$, and females $>88 \mathrm{~cm}$; (ii) fasting blood glucose concentration $\geq 110 \mathrm{mg} / \mathrm{dl}$ or receiving drugs for diabetes medication; (iii) triglyceride levels $\geq 150 \mathrm{mg} / \mathrm{dl}$; (iv) HDL-cholesterol levels less than < $40 \mathrm{mg} / \mathrm{dl}$ in males, <50 mg/dl in females; or receiving medications for dyslipidemia (v) systolic blood pressure value $\geq 130 \mathrm{mmHg}$ and/or diastolic $\geq 85 \mathrm{mmHg}$; and/or receiving antihypertensive agents.

\section{Neuroradiological evaluation}

Cranial magnetic resonance Imaging (MRI) was performed using 3T MR system (Achieva; Philips Medical Systems, Netherlands). All images including axial $T 1$ and axial T2 weighted images and fluid-attenuated inversion recovery (FLAIR) sequences were acquired. SCIs were documented while the lesions had were $\leq 15 \mathrm{~mm}$ in diameter, hyperintensity on a T2 sequence and FLAIR scan, hypointensity on a T1 sequence, without neurological symptoms and findings. Neuroradiologic assessment were performed by using Fazekas White Matter Lesion Scale [17]. In this scale, white matter hyperintensities were classified into four grades; Grade $0=$ lack of hyperintensities on periventricular white matter; Grade 1= frontal or occipital cap or thin line surrounding lateral ventricle; Grade 2= halo image around lateral ventricles; Grade 3= asymmetric deep white matter hyperintensities. All sequences were interpreted by an experienced neuradiologist.

\section{Cognitive assessment}

An experienced clinical psychologist applied the neuropsychological tests including various cognitive domains, such as executive functioning, verbal, and visual memory, and 
visuospatial abilities. All participants performed the selected tests for all cognitive skills. Neuropsychological tests were defined below:

Wechsler adult intelligent scale-revised (WAIS-R) digit span and similarities test: WAIS-R digit span test evaluates the attention, short-term, and working memory performance. Under normal circumstances, an adult could repeat seven digits in a forward sequence which indicates the mean limit of the human information storage capacity. No more than two digits should differ from forward digit span scores when performing backward digit span test. It has been adapted to Turkish by Epir and İskit et al. [18].

WAIS-R similarities test determines the abstract verbal reasoning of the frontal lobe. Subjects are responded how two seemingly dissimilar items could be similar. Patients with decline in abstract verbal reasoning could not identify the differences between these items [19].

Verbal fluency test: This test is a tool to assess executive and linguistic functions [20]. It has been standardized to Turkish by Tumac et al. Participants say the words beginning with the letter F, A, and S (in Turkish K, A, and S) on their own in a one- minute period [21]. Semantic fluency test has performed by asking the subjects to name as many different animals, fruits, and professions as they could in one minute time per category. The final score is the total number of responded items during three minutes [20].

Stroop test: This test evaluated the susceptibility to interference and the inability to inhibit inappropriate automatic responses by tasks that provoke competing responses [22]. It has been adapted to Turkish and is called “Tubitak Bilnot Battery” by Karakaş et al. [23]. Prolonged response time and the presence of many errors and corrections in this test represent frontal dysfunction [22].

Clock drawing test: This test is used for screening verbal, visuoconstructive, and spatial abilities. Various application methods have been developed and could be used for the assessment. In a classic method, patients performed to draw a clock, then put all the numbers with setting the hands for a time of 11.10 [24]. Turkish validation and reliability were performed by Cangöz et al. [25].

Öktem verbal memory processes test: This test contains a world-list learning scheme that performed in two steps. In the first step, 15 words were read 10 times to the patient by the clinician. In the second step, patients respond to these 15 words after 45 minutes (free recall). After both of these steps, the total response time that a patient could remember and repeat the words defined by the total learning score. This test measures working memory, retrieval skills, learning, and retention of learned information [26].

Wechsler Memory Scale-Revised visual memory test (WMS-R): This scale is a comprehensive psychometric test that evaluates attention, verbal and visual memory. In addition, the visual reproduction subtest of WMS-R reflects visual perceptual or constructional functioning performance [27]. Turkish reliability and validity of this test was performed by Mollahasanoglu et al. [28].

Benton Judgment of line orientation test: This test assesses visuospatial functions that are commonly related to right parietal lobe [29]. Turkish validity and reliability were established by the project of BILLNOT battery [30].

\section{Statistical analysis}

The statistical package for social sciences (SPSS) 17.0 (IBM Corporation, USA) was used for the analysis. Descriptive data was defined by numbers $(\mathrm{n})$, mean \pm standard deviation 
(SD), and percentages (\%). Chi-square test was performed to analyze categorical parameters. Normality tests were carried out for all variables. Independent sample t-test and MannWhitney $U$ test were performed for normally and non-normally distributed variables, respectively. For the comparison of cognitive test performances between the patient groups, all subscales were transformed into $\mathrm{z}$ scores and composite $\mathrm{z}$ scores were measured to determine the decline in each cognitive domain (executive functions, memory, and visuospatial functions). The z-scores of negative components in the cognitive tests were multiplied by -1 and added to positive components of the scales to prevent biased scores. Partial correlation analysis was used to evaluate the association between cognitive test scores and syndrome-related variables in patients with MetS. In this analysis, we adjusted confounding factors such as age, gender, and educational level. Conditions with a $p$ - value of $\leq 0.05$ were considered statistically significant.

\section{Results}

\section{Demographic and clinical characteristics}

We analyzed 91 consecutively patients with MetS [47 patients with SCIs (36 women, 11 men) and 44 patients without SCIs (33women, 11 men)] who were admitted to the endocrinology clinic between July 2009September 2010. No statistical difference was found between sociodemographic parameters such as gender, smoking status among the groups. However, age was significantly higher, and educational level was lower in MetS

Table 1. Sociodemographic, clinical, and cognitive features of MetS patients with and without silent cerebral infarcts (SCIs).

\begin{tabular}{|l|c|c|c|}
\hline Variables & $\begin{array}{c}\text { Patients with SCI } \\
(\mathbf{n = 4 7 )}\end{array}$ & $\begin{array}{c}\text { Patients without SCI } \\
(\mathbf{n = 4 4 )}\end{array}$ & $\boldsymbol{p}$ \\
\hline Age (years) & $45.85 \pm 6.83$ & $40.14 \pm 8.96$ & $\mathbf{0 . 0 0 1}$ \\
\hline Gender (female, $\mathbf{n , ~ \% ) ~}$ & $36(76.6)$ & $33(75)$ & 0.86 \\
\hline Education (years) & $7.08 \pm 2.91$ & $8.47 \pm 3.67$ & $\mathbf{0 . 0 5}$ \\
\hline Current or past smoker (n, \%) & $21(44.7)$ & $18(40.9)$ & 0.59 \\
\hline Waist circumference (cm) & $113.35 \pm 12.21$ & $115.47 \pm 13.42$ & 0.52 \\
\hline Family history of MetS (n, \%) & $27(57.4)$ & $30(68.2)$ & 0.29 \\
\hline Hypertension (n, \%) & $30(63.8)$ & $10(22.7)$ & $<\mathbf{0 . 0 0 1}$ \\
\hline Diabetes mellitus (n, \%) & $23(48.9)$ & $12(27.3)$ & $\mathbf{0 . 0 3 4}$ \\
\hline Dyslipidemia (n, \%) & $45(95.7)$ & $42(95.5)$ & 0.94 \\
\hline Homocysteine (5-15 $\boldsymbol{\mu m o l} / \mathbf{l} \mathbf{)})$ & $15.01 \pm 5.38$ & $14.77 \pm 3.97$ & 0.71 \\
\hline Protein C & $118.38 \pm 25.66$ & $115.75 \pm 15.82$ & 0.85 \\
\hline Protein S & $101.13 \pm 15.64$ & $99.91 \pm 17.97$ & 0.73 \\
\hline Executive functions & $-.54 .34 \pm 23.27$ & $-52.52 \pm 22.01$ & 0,703 \\
\hline Memory functions & $0.17 \pm 4.12$ & $-.0 .18 \pm 3.98$ & 0,672 \\
\hline Visuospatial functions & $0.06 \pm 1.34$ & $0.06 \pm 1.93$ & 0.756 \\
\hline
\end{tabular}

Variables are presented mean \pm standard deviation. MetS= metabolic syndrome, SCIs=silent cerebral infarcts. 
patients with SCI $(+)(p=0.001$, and $p=0.05$, respectively). The diagnosis of hypertension and diabetes mellitus were significantly frequent ( $p<0.001$, and $p=0.034$, respectively) in SCI (+) patients, while family history of MetS, waist circumference, dyslipidemia, serum homocysteine, protein $\mathrm{C}$, and protein $\mathrm{S}$ levels did not differ among SCI (+) and SCI (-) groups. Comparison of demographic and clinical features of MetS patients with and without SCIs was given in Table 1 .

\section{Neuroradiologic evaluation}

Based on the Fazekas scale, 47 patients were SCI (+) 44 patients were SCI(-) in subjects with MetS. Four patients had grade 1(caps or pencilthin lining), and 1 patient had grade 2 (smooth halo) periventricular white matter hyperintensities (PVWM). In addition, 32 patients had grade 1 (punctate foci), and 4 patients had grade 2 (beginning confluence of foci) deep white matter hyperintense signals (DWMH). Table 2 shows the frequency and localization of SCIs on cranial MRI of the patients with MetS.

Age distribution of the SCI (+) Mets patients; $3.29 \%$ were $\leq 34$ years, $5.49 \%$ were between 35-39 years, $13.19 \%$ were between 40-44 years, and $12.09 \%$ were between $45-49$ years, and $17.58 \%$ were 50 or older (Table 3 ).
Table 2. Frequency and localization of SCIs on cranial MRI of patients with MetS.

\begin{tabular}{|c|c|c|}
\hline SCI & $\mathbf{n}$ & $\%$ \\
\hline Negative & 44 & 48.35 \\
\hline Positive & 47 & 51.65 \\
\hline $\begin{array}{l}\text { PVWM } \\
\text { Grade } 1 \text { (caps or pencil-thin lining) } \\
\text { Grade } 2 \text { (smooth halo) } \\
\text { Grade } 3 \text { (irregular PVH extending into } \\
\text { the deep white matter) }\end{array}$ & $\begin{array}{l}4 \\
1 \\
-\end{array}$ & $\begin{array}{l}8.51 \\
2.12 \\
0\end{array}$ \\
\hline $\begin{array}{l}\text { DWMH } \\
\text { Grade } 1 \text { (punctate foci) } \\
\text { Grade } 2 \text { (beginning confluence of foci) } \\
\text { Grade } 3 \text { (large confluent areas) }\end{array}$ & $\begin{array}{l}32 \\
2 \\
-\end{array}$ & $\begin{array}{l}68.08 \\
4.25 \\
0\end{array}$ \\
\hline PVWM Grade 1+ DWMH Grade 1 & 6 & 12.77 \\
\hline PVWM Grade 1+ DWMH Grade 2 & 2 & 4.25 \\
\hline
\end{tabular}

$S C I s=$ silent cerebral infarcts; MRI= magnetic resonance imaging; Met $=$ metabolic syndrome; $P V W M=$ periventricular white matter hyperintensities; $D W M H=$ deep white matter hyperintense signals.

\section{Cognitive assessment}

No significant differences were detected regarding executive, memory, and visuospatial cognitive domains between subjects with SCI (+) and SCI (-) MetS groups. In a partial correlation analysis, serum homocysteine levels were negatively correlated with executive performance in SCI $(+)$ patients with MetS $(r=$

Table 3. Age distribution of MetS patients with and without silent cerebral infarcts

\begin{tabular}{|l|c|c|c|}
\hline Age groups & SCI (+) & SCI (-) & Total \\
\hline$\leq 34$ years & $3(3.29 \%)$ & $11(12.08 \%)$ & $14(15.38 \%)$ \\
\hline $35-39$ years & $5(5.49 \%)$ & $9(9.89 \%)$ & $14(15.38 \%)$ \\
\hline $40-44$ years & $12(13.19 \%)$ & $11(12.09 \%)$ & $19(20.87 \%)$ \\
\hline $45-49$ years & $11(12.09 \%)$ & $8(8.79 \%)$ & $21(23.07 \%)$ \\
\hline $50-60$ years & $16(17.58 \%)$ & $5(5.49 \%)$ & \\
\hline
\end{tabular}


Table 4. Partial correlation analysis between cognitive domains (as presented with composite $\mathrm{z}$ scores) and syndrome related variables in metabolic syndrome patients with SCIs.

\begin{tabular}{|c|c|c|c|}
\hline Parameters & Executive functions & $\begin{array}{l}\text { Memory } \\
\text { functions }\end{array}$ & $\begin{array}{l}\text { Visuospatial } \\
\text { functions }\end{array}$ \\
\hline Waist circumference $(\mathrm{cm})$ & $\begin{array}{l}r=-, 196 \\
p=, 201\end{array}$ & $\begin{array}{l}\mathrm{r}=, 805 \\
\mathrm{p}=, 42\end{array}$ & $\begin{array}{l}r=, 006 \\
p=, 968\end{array}$ \\
\hline Smoking & $\begin{array}{l}r=-, 044 \\
p=, 683\end{array}$ & $\begin{array}{l}r=, 056 \\
p=, 606\end{array}$ & $\begin{array}{l}r=, 025 \\
p=, 817\end{array}$ \\
\hline Systolic blood pressure (mmHg) & $\begin{array}{l}r=-, 018 \\
p=, 910\end{array}$ & $\begin{array}{c}r=-, 063 \\
p=, 687\end{array}$ & $\begin{array}{l}r=-, 045 \\
p=, 770\end{array}$ \\
\hline Diastolic blood pressure (mmHg) & $\begin{array}{l}\mathrm{r}=-, 029 \\
\mathrm{p}=, 853\end{array}$ & $\begin{array}{l}\mathrm{r}=-, 018 \\
\mathrm{p}=, 910\end{array}$ & $\begin{array}{l}\mathrm{r}=-, 023 \\
\mathrm{p}=, 883\end{array}$ \\
\hline Fasting blood glucose (mg/dl) & $\begin{array}{l}\mathrm{r}=, 198 \\
\mathrm{p}=, 197\end{array}$ & $\begin{array}{l}\mathrm{r}=, 121 \\
\mathrm{p}=, 434\end{array}$ & $\begin{array}{l}r=, 076 \\
p=, 625\end{array}$ \\
\hline Hba1c (\%) & $\begin{array}{l}\mathrm{r}=-, 017 \\
\mathrm{p}=, 915\end{array}$ & $\begin{array}{l}r=-, 099 \\
p=, 523\end{array}$ & $\begin{array}{l}r=, 041 \\
p=, 792\end{array}$ \\
\hline TG (mg/dL) & $\begin{array}{l}\mathrm{r}=, 175 \\
\mathrm{p}=, 255\end{array}$ & $\begin{array}{l}\mathrm{r}=-, 011 \\
\mathrm{p}=, 942\end{array}$ & $\begin{array}{l}\mathrm{r}=, 048 \\
\mathrm{p}=, 755\end{array}$ \\
\hline LDL (mg/dL) & $\begin{array}{l}\mathrm{r}=-, 151 \\
\mathrm{p}=, 329\end{array}$ & $\begin{array}{l}r=-, 282 \\
p=, 064\end{array}$ & $\begin{array}{l}\mathrm{r}=, 135 \\
\mathrm{p}=, 383\end{array}$ \\
\hline $\begin{array}{l}\text { Total cholesterol } \\
(\mathrm{mg} / \mathrm{dL})\end{array}$ & $\begin{array}{l}\mathrm{r}=-, 085 \\
\mathrm{p}=, 581\end{array}$ & $\begin{array}{l}\mathrm{r}=-, 259 \\
\mathrm{p}=, 089\end{array}$ & $\begin{array}{l}\mathrm{r}=, 138 \\
\mathrm{p}=, 371\end{array}$ \\
\hline HDL (mg/dL) & $\begin{array}{l}\mathrm{r}=, 017 \\
\mathrm{p}=, 915\end{array}$ & $\begin{array}{l}\mathrm{r}=-, 100 \\
\mathrm{p}=, 517\end{array}$ & $\begin{array}{l}r=, 133 \\
p=, 390\end{array}$ \\
\hline Homocysteine (mcmol/L) & $\begin{array}{c}r=-, 314 \\
p=, 038\end{array}$ & $\begin{array}{l}\mathrm{r}=-, 231 \\
\mathrm{p}=, 132\end{array}$ & $\begin{array}{l}r=-, 143 \\
p=, 353\end{array}$ \\
\hline Protein C (IU/dL) & $\begin{array}{l}r=, 108 \\
p=, 486\end{array}$ & $\begin{array}{l}\mathrm{r}=, 284 \\
\mathrm{p}=, 061\end{array}$ & $\begin{array}{l}r=-, 141 \\
p=, 360\end{array}$ \\
\hline Protein S (IU/dL) & $\begin{array}{l}\mathrm{r}=, 117 \\
\mathrm{p}=, 450\end{array}$ & $\begin{array}{l}\mathrm{r}=-, 155 \\
\mathrm{p}=, 314\end{array}$ & $\begin{array}{l}r=, 214 \\
p=, 162\end{array}$ \\
\hline
\end{tabular}

$S C I s=$ Silent cerebral infarcts $;$ Hbalc $=$ Hemoglobin Alc; $T G=$ triglyceride $; L D L=$ low-density lipoprotein; $H D L=$ high-density lipoprotein .

$-.314, \mathrm{p}=.038)$. No correlation was found between other MetS components and cognitive domains in this group (Table 4).

\section{Discussion}

In this study, we explored clinical factors and cognitive performances of MetS patients with and without SCIs. Additionally, we evaluated possible associations between syndrome- related factors and cognitive functions regarding executive, memory, and visuospatial domains in young and middle- aged SCI (+) patients with MetS.

SCIs are the possible neurological consequences of the prothrombotic and proinflammatory pattern of the MetS components such as; hypertension, atherogenic dyslipidemia, insulin resistance, and abdominal 
obesity. Increased free radicals, alterations of neurotrophic factors, impaired insulinstimulated glucose transport into the brain may contribute to both atherothrombotic and lacunar ischemic processes in patients with MetS [3134].

Strong association between MetS risk factors and SCIs have been well-established in epidemiologic and clinical studies [8, 31-35]. In a population-based Rotterdam Scan study, cranial MRI of 1077 non-demented participants between 60 to 90 years was compared. They found that $20 \%$ of the population had shown SCIs, and the frequency increased per year with age: $8 \%$ in the group aged between $60-65$ years and $35 \%$ at age 85 to 90 years old. In their study, there was a strong association between SCIs and hypertension $(\mathrm{OR}=2.4 ; 95 \% \mathrm{CI}, 1.7$ to 3.3), whereas no association was found between SCIs, DM, and smoking [8]. In addition, community- based Framingham Study evaluated the risk factors and the prevalence of SCI among middle-aged and elderly participants. They showed that SCI prevalence increased with age; $<8 \%$ in the $30-49$ year's age, and $>15 \%$ at $70-89$ years. Furthermore, higher systolic blood pressure (SBP), elevated plasma homocysteine, atrial fibrillation, carotid stenosis, and increased carotid intimal-medial thickness were associated with SCIs [35]. Consistent with this report, we found that the frequency of SCIs increases with age $(17.1 \%$ at age $\leq 39$ years, and $82.9 \%$ at age $\geq 40$ years, respectively). In Cardiovascular Health Study, 3.324 elderly subjects without a history of cerebrovascular disease underwent a cranial MRI scan. They reported that, $28 \%$ of these subjects had SCIs, and higher systolic and diastolic blood pressure values, carotid wall thickness, and atrial fibrillation were associated with a higher risk for cerebrovascular events [36].
However, only a few studies have been focused on the association between the risk factors and SCIs among young and middle- aged people in clinical practice. In Atherosclerosis Risk in Communities (ARIC) study, hypertension, smoking, age, alcohol use, educational level, and being African American were independently associated with white matter hyperintensities in middle-aged healthy subjects [37,38]. In our study, age was significantly higher $(\mathrm{p}=0.001)$, educational level was significantly lower $(\mathrm{p}=0.05)$, and diagnosis of hypertension and DM were more frequent $(\mathrm{p}<0.001$, and $\mathrm{p}=0.034$, respectively) in young and middle aged MetS patients with SCIs than without SCI. In a study by Park et al., higher blood pressure, abnormal glucose regulation, hypertriglyceridemia and large waist circumference were significantly related to SCIs in MetS patients aged between 40 and 59 years [39]. Similarly, Kwon and colleagues confirmed the significant role of high blood pressure and abnormal glucose regulation on SCI risk in a wide spectrum of ages (between 20-86 years) [40]. In addition, Atherosclerosis Risk in Communities Neurocognitive Study (ARIC-NCS) reported that patients with more severe diabetes (defined as elevated HbA1c levels and longer disease duration) were at high risk for white matter hyperintensities in the middle aged group [41]. Taking these into account, previous studies reported conflicting results due to the sampling strategies (differences in age groups, variability between radiological techniques, casual interferences, having a history of cerebrovascular event before the enrollment) during the methodologic process.

MetS components such as; insulin resistance, glucose intolerance, dyslipidemia, arterial hypertension, and morbid obesity constitute an important part of cognitive decline [42-44]. 
Episodes of hypoglycemia and insulinresistance in DM, arteriolosclerosis, and lipohyalinosis in small vessels due to hypertension, neuroinflammation, and altered adipokine levels in obesity may facilitate the development of cognitive impairment in patients with MetS [43-45]. Although, the exact mechanism has not been elucidated, the pathogenesis is explained with a multifactorial process regarding vascular injury caused by cerebral ischemia and non-ischemic neuronal death via neurodegeneration [45]. Recent studies have demonstrated poorer executive and memory functions in both middle- aged and elderly people with MetS [4649]. In addition, previous research has emphasized the contributing effect of cerebral ischemia on the relationship between cognitive decline and MetS components [33,50]. In our study, we observed decline in executive functions, memory performance, and visuospatial functions in $37.3 \%, 8.8 \%$, and $29.7 \%$ of MetS patients, respectively. Nevertheless, cognitive test scores did not differ between MetS patients with and without SCIs. These results may be related to the existence of a younger age population in our study. In the MetS patients with SCIs group, a significant correlation between elevated serum homocysteine levels and decline in executive functioning was observed $(\mathrm{r}=-.314, p=.038)$. Previous studies emphasized the role of increased homocysteine levels on the risk of cognitive impairment regarding episodic memory, speed of information processing, spatial learning and executive functions in elderly subjects [51-54]. However, these studies are limited to the geriatric population, and the exact mechanism of homocysteine levels on cognitive processes remained unclear. This study was limited in several ways. First, our study was carried out in a tertiary referral center with a relatively small sample size. Second, depending on the hospital's distance between densely populated areas and frequent admissions of chronic and palliative care patients to our hospital, we could not reach the targeted number of patients during the enrollment process. Third, consecutive and nonrandomized sampling may possibly cause biased results on neuropsychological test scores. Despite these limitations, this is the first prospective study comparing the possible association between syndrome- related factors, SCIs, and cognitive performance in young and middle aged subjects with MetS. Additionally, all reliable and validated cognitive tests were applied by an experienced clinical psychologist.

\section{Conclusion}

In sum, our results suggest that older age, lower educational status, hypertension, and DM are more frequent, and serum homocysteine levels are associated with executive functions in SCI (+) patients with MetS. Further longitudinal studies are needed to clarify syndrome- related factors, cognitive phenotypes, and dementia risk in patients with SCIs and MetS.

Funding: The author(s) received no financial support for the research, authorship, and/or publication of this article.

Conflict of Interest: The authors declare that they have no conflict of interest.

Ethical statement: All procedures performed in studies involving human participants were in accordance with the ethical standards of the clinical Research Ethics Committee of Kocaeli University Hospital (approval number 2009/98, AEK-12/17) and adhered to the tenets of the Declaration of Helsinki. Written and informed consent was obtained from all participants. 
Acknowledgements: We would like to thank Prof. Dr. Faik Budak for his permanent support and scientific guidance. In addition, we sincerely thank all patients and healthy volunteers who participated in our study.

\section{Open Access Statement}

This is an open access journal which means that all content is freely available without charge to the user or his/her institution under the terms of the Creative Commons Attribution NonCommercial License (https://creativecommons.org/licenses/by/4.0/). Users are allowed to read, download, copy, distribute, print, search, or link to the full texts of the articles, without asking prior permission from the publisher or the author.

Copyright (c) 2021: Author (s).

\section{References}

[1]McCracken E, Monaghan M, Sreenivasan S. Pathophysiology of the metabolic syndrome. Clin Dermatol. 2018;36(1):14-20.

[2]Alberti KG, Eckel RH, Grundy SM, et al. International Diabetes Federation Task Force on Epidemiology and Prevention; Hational Heart, Lung, and Blood Institute; American Heart Association; World Heart Federation; International Atherosclerosis Society; International Association for the Study of Obesity. Harmonizing the metabolic syndrome: a joint interim statement of the International Diabetes Federation Task Force on Epidemiology and Prevention; National Heart, Lung, and Blood Institute; American Heart Association; World Heart Federation; International Atherosclerosis Society; and International Association for the Study of Obesity. Circulation. 2009;120(16):1640-45.

[3]Bangen KJ, Armstrong NM, Au R, Gross AL. Metabolic Syndrome and Cognitive Trajectories in the Framingham Offspring
Study. J Alzheimers Dis. 2019;71(3):93143.

[4]Simmons RK, Alberti KG, Gale EA, et al. The metabolic syndrome: useful concept or clinical tool? Report of a WHO Expert Consultation. Diabetologia. 2010;53(4):6005.

[5]Kahn R, Buse J, Ferrannini E, et al. The metabolic syndrome: time for a critical appraisal. Joint statement from the American Diabetes Association and the European Association for the Study of Diabetes. Diabetologia. 2005;48(9):1684-99.

[6]Chodosh EH, Foulkes MA, Kase CS, et al. Silent stroke in the NINCDS Stroke Data Bank. Neurology. 1988;38(11):1674-79.

[7]Special report from the National Institute of Neurological Disorders and Stroke. Classification of cerebrovascular diseases III. Stroke. 1990;21(4):637-76.

[8]Vermeer SE, Koudstaal PJ, Oudkerk M, et al. Prevalence and risk factors of silent brain infarcts in the population-based Rotterdam Scan Study. Stroke. 2002;33(1):21-25.

[9]Price TR, Manolio TA, Kronmal RA, et al. Silent brain infarction on magnetic resonance imaging and neurological abnormalities in community-dwelling older adults. The Cardiovascular Health Study. CHS Collaborative Research Group. Stroke. 1997; 28(6): 1158-64.

[10] Jiménez-Balado J, Riba-Llena I, Abril O, et al. Cognitive Impact of Cerebral Small Vessel Disease Changes in Patients With Hypertension. Hypertension. 2019; 73(2):342-49.

[11]Bokura H, Yamaguchi S, Iijima K, et al. Metabolic syndrome is associated with silent ischemic brain lesions. Stroke. 2008;39(5):1607-9.

[12]Zhao J, Tang H, Sun J, et al. Analysis of cognitive dysfunction with silent cerebral 
infarction: a prospective study in Chinese patients. Metab Brain Dis. 2012; 27(1):1722.

[13] Shibata K, Nishimura Y, Otsuka K, et al. Influence of cerebral white matter hyperintensities on cognitive impairment in elderly medical patients. Geriatr Gerontol Int. 2017;17(10):1488-93.

[14] Wardlaw JM, Valdés Hernández MC, Muñoz-Maniega S. What are white matter hyperintensities made of? Relevance to vascular cognitive impairment. J Am Heart Assoc. 2015, 4(6):001140.

[15]Bokura H, Nagai A, Oguro H, et al. The association of metabolic syndrome with executive dysfunction independent of subclinical ischemic brain lesions in Japanese adults. Dement Geriatr Cogn Disord. 2010;30(6):479-85.

[16] Expert Panel on Detection, Evaluation, and Treatment of High Blood Cholesterol in Adults. Executive Summary of The Third Report of The National Cholesterol Education Program (NCEP) Expert Panel on Detection, Evaluation, And Treatment of High Blood Cholesterol In Adults (Adult Treatment Panel III). JAMA. 2001; 285(19):2486-97.

[17] Mäntylä R, Erkinjuntti T, Salonen O, et al. Variable agreement between visual rating scales for white matter hyperintensities on MRI. Comparison of 13 rating scales in a poststroke cohort. Stroke. 1997;28(8):161423.

[18] Epir S, Iskit Ü. Wechsler Yetişkinler Zeka Ölçeği Türkçe çevirisinin ön analizi ve üniversite danışmanlık merkezlerindeki uygulama potansiyeli. Hacettepe Sosyal ve Beşeri Bilimler Dergisi, 1972; 4: 198-205.

[19] Wechsler D, Manual for the Wechsler Adult Intelligence Scale-Revised. In:
Psychological Corporation, New York; 1981.

[20] Benton A. Differential behavioral effects on frontal lobe disease. Neuropsychologia. 1968; 6: 53- 60.

[21]Tumaç A. Normal deneklerde, frontal hasarlara duyarlı bazı testlerde performansa yaş ve eğitimin etkisi, yüksek lisans tezi, İstanbul 1997.

[22] Golden, CJ (1978) Stroop Color and Word Test: A Manual for Clinical and Experimental Uses. Chicago, Illinois; 1978. p.1-32.

[23] Karakas S, Eski R, Basar E. BILNOT Battery, Standardized neuropsychological tests for Turkish culture. 32nd National Congress of Neurology Congress Book. 1997. p. 43-70.

[24]Freedman MI, Leach L, Kaplan E, et al. Clock Drawing. Oxford: Oxford University Press, 1994.

[25]Cangöz B, Karakoç E, Selekler K. Saat Çizme Testinin 50 yaş ve üzeri Türk yetişkin ve yaşlı örneklemi üzerinde norm belirleme ve geçerlik-güvenirlik çalışmaları. Turkish J Geriatrics 2006; 9: 136-42.

[26]Öktem Ö. Sözel bellek süreçleri testi (SBST): Bir ön çalışma. Nöropsikiyatri Arşivi, 1992; 29: 196-206.

[27] Wechsler D: Wechsler Memory ScaleRevised Manual. San Antonio, Psychological Corporation, 1987.

[28] Mollahasanoğlu A, Normal deneklerde bir grup görsel ve sözel bellek testleri performansına yaş ve eğitimin etkisi. yüksek lisans tezi, İstanbul 2002.

[29] Michael D. Franzen. Reliability and Validity in Neuropsychological Assessment. Springer Science \& Business Media.2000. p. 156. 
[30] Karakaş S. Bilnot Bataryası El Kitabı: Araştırma ve Geliştirme Çalışmaları, Ankara: Dizayn Ofset 2. Bask1, 2006.

[31] Eguchi K, Kario K, Hoshide S, et al. Greater change of orthostatic blood pressure is related to silent cerebral infarct and cardiac overload in hypertensive subjects. Hypertens Res. 2004; 27(4):235-41.

[32]Dearborn JL, Schneider AL, Sharrett AR, et al. Obesity, Insulin Resistance, and Incident Small Vessel Disease on Magnetic Resonance Imaging: Atherosclerosis Risk in Communities Study. Stroke. 2015; 46(11):3131-36.

[33] Alkan E, Taporoski TP, Sterr A, et al. Metabolic syndrome alters relationships between cardiometabolic variables, cognition and white matter hyperintensity load. Sci Rep. 2019; 9(1): 4356.

[34]Friedman JI, Tang CY, de Haas HJ, et al. Brain imaging changes associated with risk factors for cardiovascular and cerebrovascular disease in asymptomatic patients. JACC Cardiovasc Imaging. 2014; 7(10):1039-53.

[35]Das RR, Seshadri S, Beiser AS, et al. Prevalence and correlates of silent cerebral infarcts in the Framingham offspring study. Stroke. 2008; 39(11): 2929-35.

[36] Bernick C, Kuller L, Dulberg C, Longstreth WT Jr, Manolio T, Beauchamp N, Price T; Cardiovascular Health Study Collaborative Reseach Group. Silent MRI infarcts and the risk of future stroke: the cardiovascular health study. Neurology. 2001; 57(7): 122229.

[37]Liao D, Cooper L, Cai J, et al. Presence and severity of cerebral white matter lesions and hypertension, its treatment, and its control. The ARIC Study. Atherosclerosis Risk in Communities Study. Stroke. 1996; 27(12): 2262-70.
[38] Power MC, Deal JA, Sharrett AR, et al. Smoking and white matter hyperintensity progression: the ARIC-MRI Study. Neurology. 2015; 84(8): 841-48.

[39]Park K, Yasuda N, Toyonaga S, et al. Significant associations of metabolic syndrome and its components with silent lacunar infarction in middle aged subjects. $\mathrm{J}$ Neurol Neurosurg Psychiatry. 2008; 79(6): 719-21.

[40] Kwon HM, Kim BJ, Lee SH, et al. Metabolic syndrome as an independent risk factor of silent brain infarction in healthy people. Stroke. 2006; 37(2):466-70.

[41]Biessels GJ, Despa F. Cognitive decline and dementia in diabetes mellitus: mechanisms and clinical implications. Nat Rev Endocrinol. 2018;14(10):591-604.

[42] J. Jimenez-Balado, I. Riba-Llena, O. Abril, et al. Cognitive impact of cerebral small vessel disease changes in patients with hypertension. Hypertension. 2019;73(2): 342-49.

[43] Cournot M, Marquie JC, Ansiau D, et al. Relation between body mass index and cognitive function in healthy middle-aged men and women. Neurology. 2006; 67(7): 1208-14.

[44] Schneider ALC, Selvin E, Sharrett AR, et al. Diabetes, Prediabetes, and Brain Volumes and Subclinical Cerebrovascular Disease on MRI: The Atherosclerosis Risk in Communities Neurocognitive Study (ARICNCS). Diabetes Care. 2017; 40(11):151421.

[45]Borshchev YY, Uspensky YP, Galagudza MM. Pathogenetic pathways of cognitive dysfunction and dementia in metabolic syndrome. Life Sci. 2019; 237:116932.

[46] Foret JT, Oleson S, Hickson B, et al. Metabolic Syndrome and Cognitive 
Function in Midlife. Arch Clin Neuropsychol. 2021;36(6):897-907.

[47] Rouch I, Trombert B, Kossowsky MP, et al. Metabolic syndrome is associated with poor memory and executive performance in elderly community residents: the PROOF study. Am J Geriatr Psychiatry. 2014; 22(11):1096-104.

[48] Segura B, Jurado MA, Freixenet N, et al. Mental slowness and executive dysfunctions in patients with metabolic syndrome. Neurosci Lett. 2009;462(1):49-53.

[49]Lai MMY, Ames DJ, Cox KL, et al. Association between Cognitive Function and Clustered Cardiovascular Risk of Metabolic Syndrome in Older Adults at Risk of Cognitive Decline. J Nutr Health Aging. 2020; 24 (3):300-304.

[50] Yamawaki M, Wada-Isoe K, Yamamoto M, et al. Association of cerebral white matter lesions with cognitive function and mood in Japanese elderly people: a population-based study. Brain Behav. 2015; 5(3): e00315.

[51]Hooshmand B, Solomon A, Kåreholt I, et al. Associations between serum homocysteine, holotranscobalamin, folate and cognition in the elderly: a longitudinal study. J Intern Med. 2012; 271 (2): 204-12.

[52] Nurk E, Refsum H, Tell GS, et al. Plasma total homocysteine and memory in the elderly: the Hordaland Homocysteine Study. Ann Neurol. 2005; 58(6):847-57.

[53] van den Kommer TN, Dik MG, Comijs HC, et al. Homocysteine and inflammation: predictors of cognitive decline in older persons? Neurobiol Aging. 2010; 31(10):1700-9.

[54]Narayan SK, Saxby BK, Firbank MJ, et al. Plasma homocysteine and cognitive decline in older hypertensive subjects. Int Psychogeriatr. 2011; 23(10):1607-15. 